\title{
Recontextualising Ece Temelkuran in the UK: A Paratextual Look at the English Translations of Her Works
}

\section{Ece Temelkuran'ı Birleşik Krallık'ta Yeniden Bağlamlaştırmak: Eserlerinin İngilizce Çevirilerine Yan Metinsel Bir Bakış}

\author{
Aysun $\mathrm{KIRAN}^{1}$ (1)
}

${ }^{1}$ Res. Assist., PhD, Marmara University, Faculty of Arts and Sciences, Department of Translation and Interpretation, İstanbul, Turkey

ORCID: A.K. 0000-0003-1551-3776

\section{Corresponding author:}

Aysun KIRAN,

Marmara University, Faculty of Arts and Sciences, Department of Translation and Interpretation, İstanbul, Turkey

E-mail: aysun.kiran@marmara.edu.tr

Submitted: 19.02.2020

Revision Requested: 24.02.2020

Last Revision Received: 12.06 .2020

Accepted: 24.07.2020

Citation: Kiran, A. (2020).

Recontextualising Ece Temelkuran in the UK: A paratextual look at the English translations of her works. Litera, 30(2), 621-643.

https://doi.org/10.26650/LITERA2020-0046

\begin{abstract}
Literary and non-literary works from Turkey have become more visible in the UK market through translations since the early 2000s. This increased interest in Turkish titles has been accompanied by the expectation from the authors to speak for their communities and represent their countries. Hence, translation has constituted a site of political signification in that Turkish authors' works have largely been discussed in view of the information and/or criticism they provide about their social and political contexts of origin. Following in the footsteps of the literature on the promotion and reception of Turkish authors in translation, this article examines the English translations of Ece Temelkuran's selected works with a focus on how they were presented in the UK. Specifically, it will offer a descriptive analysis of the paratextual elements of Turkey: The Insane and The Melancholy and Women Who Blow on Knots. In doing so, the article will focus mainly on the front and back covers, translated titles, visuals and blurbs of the selected books. This study shows that the translator's work is more likely to be recognised when a Turkish title is selected for translation for its literary success in its country of origin rather than for the timeliness of its political commentary. In parallel, it will be argued that the selection of an author's books for publication in the UK based on their literary merit provides more room for that author to release the burden of political signification.
\end{abstract}

Keywords: Paratexts, book covers, translated Turkish literature, translations into English, Ece Temelkuran

öz

Türkiye'den çıkan edebi ve edebiyat dışı çalışmalar 2000'li yılların başından itibaren Birleşik Krallık pazarında çeviriler yoluyla daha görünür hale gelmiştir. Türkçe eserlere yönelik bu artan ilgiye aynı zamanda yazarların kendi toplulukları için konuşması ve kendi memleketlerini temsil etmesi yönündeki beklenti de eşlik etmiştir. Bu nedenden dolayı, çeviri, Türk yazarların eserlerinin çoğunlukla içinden çıktıkları toplumsal ve siyasi bağlamlara dair sundukları bilgi ve/ya eleştiri temelinde tartışııması bakımından bir politik anlamlandırma alanı olmuştur. Çeviri eserleri yayınlanan Türk yazarların 
tanıtılması ve alımlanmasına yönelik çalışmaların yapıldığı literatürün izinden giderek bu makalede, Ece Temelkuran'ın seçilmiş eserlerinin İngilizce çevirileri, bu çevirilerin Birleşik Krallık'ta nasıl sunulduğu noktasına odaklanılarak incelenmektedir. Spesifik olarak, çalışmada Temelkuran'ın Türkiye: Çılgın ve Hüzünlü ile Düğümlere Üfleyen Kadınlar adlı eserlerinin İngilizce çevirilerinin yan metinsel ögelerinin betimsel analizi sunulacaktır. Bunu yaparken, ağırıklı olarak, seçilen kitapların ön ve arka kapaklarına, kitap başlıklarının çevirilerine, kullanılan görsellere ve tanıtıcı yazılara odaklanılacaktır. Çalışmada, Türkçe bir eserin çevirisinin, kitabın içerdiği politik yorumun güncelliğinden çok, o kitabın ilk basıldığı ülkedeki edebi başarısından ötürü yapılmış bir çeviri olması durumunda çevirmenin yaptığı işin tanınmasının daha olası olduğu gösterilecektir. Buna paralel olarak, bir yazarın kitaplarının edebi değerine dayalı olarak Birleşik Krallık'ta yayınlanmak üzere seçilmesinin o yazarın, üzerindeki politik anlamlandırma yükünden kurtulması açısından ona daha fazla alan sağladığı savunulmaktadır.

Anahtar Kelimeler: Yan metinler, kitap kapakları, çeviri Türk edebiyatı, İngilizceye çeviriler, Ece Temelkuran 


\section{Introduction}

Literary and non-literary works from Turkey have become more visible in the English-speaking and specifically UK markets through translations since the early 2000s. The number of novels translated from Turkish into English between 1980 and 2000 increased from fourteen to forty in the following ten years (2000-2010) (Akbatur, 2011 , p. 166). This increased interest in Turkish titles in the last decade has resulted from a combination of factors. One key event was that Orhan Pamuk won the Nobel Prize for Literature in 2006, which "has had a direct impact on the promotion of works of Turkish literature abroad" (Akbatur, 2011, p. 163). Another significant development was that, in 2005, Turkey's Ministry of Culture and Tourism initiated the TEDA project, "a subvention project for the publication of Turkish cultural, artistic and literary works in foreign languages" (Tahir Gürçağlar, 2015, p. 138). Additionally, it is also important to note the promotional efforts of literary agencies, such as the Kalem Agency and Anatolia-Lit Agency, to translate Turkish books into other languages (Uslu, 2012, p. 14).

On the other hand, Duygu Tekgül indicates that "the main trend in the West has been to translate and publish mainstream works, or those that have already gained recognition in Turkey" (Tekgül, 2011, p. 26). This point arguably ties in with "the burden of translation", which Arif Dirlik uses to describe the assumptions or expectations that "minority writers" encounter whilst introducing their works in transnational contexts (Dirlik, 2002, p. 216). Accordingly, the burden of translation involves the expectation from these writers to speak for a group to which they belong and, relatedly, the treatment of their works in view of their representational potential of that group (Dirlik, 2002, p. 216). In parallel, Alev Adil echoes Dirlik's observation by drawing attention to "the burden of political signification forced upon Turkish writers" in the promotion and critical reception of their works (Adil, 2006, p. 1). Crucially, an overview of the scholarship on the representation of translated literature from Turkey suggests that this burden is particularly more pronounced in the case of Turkish women writers. Considering their status within this framework of publication, Arzu Akbatur argues that the novel stands out as "the genre which made it possible for Turkish women writers to make their voices heard" in the last decade (Akbatur, 2011, p. 168, emphasis in original). It is beyond the scope of this study to provide a comprehensive survey of women writers from Turkey that have been represented in the West through translation (Paker, 2001; Akbatur, 2011). However, in a complementary manner to Akbatur's 
argument, Duygu Tekgül highlights that "between 2000 and 2010, the number of translations of novels by women writers almost equals that of novels by male writers" (Tekgül, 2011, p. 25).

Despite this upward trend in the visibility of female voices from Turkey in the global literary markets, these numbers do not translate into a shift away from the mindset that expects these women writers to speak for their communities and highlight their stories of victimhood. For instance, Müge Gürsoy Sökmen, a well-known literary agent and the founder of Metis Publishing, suggests that most publishers in the West are interested in publishing "something" that would "fulfil the role expected from the Turks in literature" and reinforce their conceptions of Turkey (Gürsoy Sökmen, 2002). Accordingly, these publishers' approach to Turkish women writers is no less different, since their understanding of "good stories to tell" corresponds to "good literary documentaries of family violence, wife-beating, harassment from the violent Orient" (Gürsoy Sökmen, 2002).

Likewise, Adalet Ağaoğlu, an acclaimed author of Turkey, states in a 2007 interview with the literary critic Semih Gümüş that a Turkish writer would stand a bigger chance of being represented in the West through translations "if s/he said her/his work recounted the story of oppressed women and advocated women's rights" (Gümüş, 2007, my translation). Ağaoğlu reinforces her argument by adding that a publisher's editor in London once offered to introduce her as "the oppressed woman of Islam," which the author refused (Gümüş, 2007). These examples suggest that literary and non-literary works of Turkish authors have so far largely been treated in the West, and in the UK, as "a source of socio-political commentary or documentary rather than as literary works per se" (Tekgül, 2011, p. 9). Taking its cue from this point, the present article examines two English translations of Ece Temelkuran, a best-selling author and political commentator of Turkey, with a focus on the ways in which they were introduced to the readership in the UK.

Temelkuran has been having an increasing media presence in the UK since 2013 when she attended the London Book Fair and gave a talk on Turkey. This was one year after she was fired from the Habertürk daily in early 2012 due to her criticism of the government for an attack on smugglers, resulting in the death of 32 civilians. After the loss of her job as a journalist, Temelkuran focused her attention on literature and published fictional and non-fictional works in Turkey and abroad. Therefore, in the case 
of a woman author such as Temelkuran, the burden of political signification may be both inevitable and desirable in the reception and promotion of her works. However, there is a lack of scholarly interest in examining Temelkuran's literary presence in the UK from a translational and paratextual perspective. This study aims to fill this gap in the literature, and extend one's knowledge of the recontextualisation of Turkish women writers through translation in English-speaking countries.

To achieve this end, the article will offer a descriptive analysis of the paratextual elements of Women Who Blow on Knots and Turkey: The Insane and The Melancholy. The former, a road trip novel, was first published with the title of Dügümlere Üfleyen Kadınlar in Turkey in 2013. It was translated from Turkish into English by Alexander Dawe and published by Parthian Books in the UK in 2017. The latter, a non-fictional book on Turkey, was translated from Turkish by Zeynep Beler into English and published by Zed Books in 2016. A comparative look at the peritexts of the selected books will enable us to identify how Turkish literature was recreated and a literary voice from Turkey was recontextualised in the UK by the act of translation in view of the cultural and political context in which these translations were made accessible. Additionally, this study will draw on different epitexts such as publicity material from book festivals, reviews and interviews to show how the paratexts within and outside the books complement one another in presenting Temelkuran and her works. Based on the findings of the analysis, I will argue that the selection of an author's books for publication in the UK based on their literary merit provides more room for the author to release the burden of political signification.

The article is organised as follows. First, the aim and methodology section will elucidate in what respects paratexts are worth examining in terms of their role in the consumption and reception of translated literature. It will also provide a brief survey of the works that explored certain examples of translated literature from Turkey from a paratextual point of view. Second, this section will be followed by the presentation of the findings about the peritextual elements of Temelkuran's selected books, published in the UK. This peritextual analysis will also be reinforced by the presentation and reception of the author and her books in the selected epitexts. Third, and finally, the article will discuss these findings in terms of how Temelkuran's case echoes, challenges or subverts the burden of translation and political signification attributed to Turkish writers in English translation. 


\section{Aim and Methodology}

In his work entitled Paratexts: Thresholds of Interpretation, Gérard Genette defines paratexts as "verbal or other productions" that "surround" and "extend" a text "in order to present it" and "to ensure the text's presence in the world, its 'reception' and consumption in the form ... of a book" (Genette, 1997, p. 1). Genette divides paratexts into two categories as "peritexts" (elements that are placed "within the same volume") and "epitexts" ("distanced elements" that "at least originally, are located outside the book" (Genette, 1997, pp. 4-5). Accordingly, examples of peritexts include"titles, subtitles, pseudonyms, forewords, dedications, prefaces, epilogues and framing elements such as the cover and blurb" (Munday, 2016, p. 242). Examples of epitexts are "marketing and promotional material, which may be provided by the publisher, correspondence on the text by the author and also reviews and academic and critical discourse on the author and text which are written by others" (Munday, 2016, p. 242).

In his theoretical framework, Genette also makes a clear distinction between the peritext and epitext in terms of their paratextual function. Accordingly, the epitext's function "is not always basically paratextual" (Genette, 1997, p. 345). This forms a contrast to "the inseparability of the peritext from its paratextual function" (Batchelor, 2018, p. 11). In other words, the peritext is "by definition paratextual", because "any material physically attached to the text by definition conveys comment on the text, or presents the text to readers, or influences how a text is received" (Batchelor, 2018, p. 12). However, unlike the peritext, the epitext serves a paratextual function only when it fulfils any one of these three functions.

On the other hand, when the epitext has its paratextual function, it may facilitate a better understanding of "how publishers select, present and translate literature from other cultural contexts" (Alvstad, 2012, p. 90). In this case, the epitextual material may serve as a complement to the paratextual analysis in a study like this one, which is mainly focused on the peritexts. This is particularly worth noting, since the spatial distinction between the peritext and epitext that originally exists does not prevent the latter's "later admission to the peritext" (Genette, 1997, p. 344). The appearance of an epitext such as Boyd Tonkin's review as a peritext on the front and back cover of Women Who Blow on Knots will be discussed as a case in point in this regard in the section below. 
Relatedly, despite its subordinate position in relation to the text, the paratext is "crucial in guiding the reading process" (Munday, 2016, p. 242). In other words, a paratext "can make known an intention or an interpretation by the author and/or the publisher" (Genette, 1997, p. 11, emphasis in original). In the same vein, Gisele Sapiro stresses that the publisher's strategies involved in presenting a book are worth exploring in terms of their capacity "to assign meaning to the translated text, even before the critical reception" (Sapiro, 2008, p. 163). Therefore, an inquiry into a book's paratextual elements will serve to elucidate the publisher's role in informing the (re)presentation of translated (literary or non-literary) works in view of the demands of the target culture in question.

However, Genette considers translation as a form of paratext to its original source, which is problematised by Şehnaz Tahir Gürçağlar (Tahir Gürçağlar, 2002, 2011). Accordingly, the significance of studying paratexts lies in that they "bridge translated texts with their readers" (Tahir Gürçağlar, 2011, p. 113). Likewise, Arzu Eker Roditakis explains the significance of pursuing a paratextual study of a translated text by pointing to the double function of paratexts: "they are specially designed to influence a readership's reception of a text, and at the same time they mirror that reception" (Eker Roditakis, 2012, p. 41). An inquiry into the paratexts of translations itself hence involves an attempt to comprehend "a translational process by which the target culture constructs the source culture and literature" (Alvstad, 2012, p. 90). Therefore, the study of paratexts has so far been deemed in translation studies as insightful, albeit not as in-depth as the one that a textual analysis would offer, about the dynamics of the wider sociocultural and political context in which translations are situated.

Several scholars endeavoured to explore the role of paratexts in the recontextualisation of Turkish literature and authors through translations and/or retranslations in different literary contexts. For instance, Arzu Eker Roditakis carried out a paratextual analysis of Ahmet Ümit's A Memento for Istanbul and its Greek translation, along with references to several other examples, to identify how Turkish novels were recontextualised for the Greek readership (Eker Roditakis, 2012). Arzu Akbatur provided an illuminating discussion on the role of paratexts in the representation of Turkish literature through a comparative analysis of the paratexts of Elif Şafak's The Bastard of Istanbul and its Turkish translation (Akbatur, 2009). Şule Demirkol Ertürk examined the English retranslations of Ahmet Hamdi Tanpınar's The Time Regulation Institute through a paratextual point of view (Demirkol Ertürk, 2019). This perspective enabled the scholar to identify"the determining role of agents, especially the publishers, translators, critics, and reviewers in the process 
of legitimating translated works" (Demirkol Ertürk, 2019, p. 137). Given the deliberate and collaborative nature of the process involved in translations, these paratextual studies have further testified that "no translation is the production of only the translator" (von Flotow, 2012, p. 129).

Drawing on these insights into the functions of paratexts in the promotion and reception of translations, the present article aims to identify how Temelkuran and her works are recontextualised in the UK. This identification will enable us to pinpoint what purpose(s) this recontextualisation serves in terms of building bridges between this female author as an oppositional voice from Turkey and the English readership. Methodologically, the article will examine the peritexts, including the front and back covers, the author's biography and the translator's bio, if applicable. Different epitexts will also be referred to as a complement to the peritextual analysis. In this respect, the publicity material from book festivals, the interviews with the author and the translators regarding the process of preparing the books for publication will also be considered to gain an insight into the stance of the publishers and editorial decisions. These sources will provide an understanding of how these translations are intended to affect the readers' reception of Temelkuran and her selected works and what functions they fulfil in the target literary industry.

Before proceeding further into the reasons for selecting these two books for the focus of analysis here, it may be helpful to provide a brief insight into their content. In Turkey: The Insane and The Melancholy, Temelkuran presents an overview of the transformation that Turkey has gone through since its establishment in 1923 by dividing the book into three sections entitled "yesterday", "today" and "tomorrow." The author describes the work as "an orientation tour of her Turkey" for beginners, intended to explain the country's complex story through her personal experiences (Leser, 2016). Published in Germany and the UK in 2015 and 2016, respectively, the book was not (and still has not been) published in the author's country of origin. Although the reasons for that lack of publication have not been explicitly stated anywhere, it is likely to be the case due to the current social and political situation in the country, given that the author currently lives on a self-imposed exile in Zagreb, Croatia.

As for Women Who Blow on Knots, Temelkuran narrates the story of four women, from four different Muslim countries, who set out on a journey from Tunisia to Lebanon against the background of the Arab Spring. The novel won the Scottish First Book Award 
at the 2017 International Edinburgh Book Festival, being selected from among "50 debut novels and short story collections for adults and young adults featured in the Book Festival public programme" of that year (Edinburgh International Book Festival, 2017, para. 1). While praising the novel, Nick Barley, the book festival's director, referred to Temelkuran as "a fearless journalist whose writing about Turkey and its neighbouring countries deserves to be read widely across the world" (Edinburgh International Book Festival, 2017, para. 4). The epitexts such as this news from a book festival and the comments on the author and her literary success also serve as the "mediators between the text and the reader," thereby informing the reader's reception even before the reading process begins (Kovala, 1996, p. 120). Additionally, when the award was granted to Temelkuran, the author was already known in the UK due to her appearances on platforms such as The BBC and Channel Four News and contributions to newspapers such as The Guardian.

These two books were selected for the analysis here based on two reasons. The first reason pertains to the inaccessibility of the source text and its paratexts in the case of The Insane and The Melancholy. Therefore, unlike Women Who Blow on Knots, it is not possible for us to make a comparison between the Turkish and English versions of The Insane and The Melancholy in terms of their paratexts, which renders the English translation of the latter a case particularly worthy of scholarly attention. Considered together with the character of the book as a political commentary, the absence of its Turkish publication arguably provides us with a basis on which to compare and contrast the presentation of these translations in the UK. Second, the differences in the genre of these two books will provide us with an opportunity to note the parallels and divergences between the two publishers in the recontextualisation of Temelkuran in the UK. The article will also pay attention to the differences, if any, in the approach of each publishing house to the translators involved. The study will draw its conclusions based on the information in the interviews with the translators, Zeynep Beler and Alexander Dawe, which are accessed in online platforms.

\section{Findings}

To start with the front cover of Turkey: The Insane and The Melancholy, all the texts therein are given in the capital letters, as seen in Figure 1. The author's name is placed on the top, and the first part of the title (Turkey) is placed right below in a much larger font size. The subtitle (The Insane and The Melancholy) is left-aligned, written in the 
same font size as the author's name and located in the bottom half of the cover in a manner that does not block the image. Crucially, the cover does not provide any piece of information to show that the book is in fact a translation. A quote ("Engrossing and Intimate") by Patrick Cockburn, an award-winning columnist and the Middle Eastern correspondent of The Independent, is selected to appear on the cover.

The cover image presents an elderly man with a white beard, sitting on a sofa with an ambiguous expression on his face and looking away from the camera. His expression is unclear in terms of whether it conveys sadness or anger. Further, no information is provided on any part of the book as to the identity of the man and/or the source context from which the photo was taken. It was only through a personal conversation with Temelkuran that I learned that he was the last person left in his building in Tarlabaşı, Istanbul, resisting against the forced displacement and gentrification in protest of the urban renewal policies. It is important to note that this information, and the lack thereof, is likely to affect the reader's perception of the book, as will be discussed below. The peritexts that follow the cover include a page with the full title and subtitle and the page on which the author's and translator's name are written. Additionally, the sections entitled "praise for the book" and "about the author" are followed by a contents page and the main body of text by an index to help the reader navigate through the book.

The blurb on the back cover notes that the author guides the reader through her beloved country. Accordingly, in doing so, Temelkuran provides "a beautifully rendered account of the struggles, hopes, and tragedies that make Turkey what it is today." In a similar manner to the front cover, the recognition of the translator's name or any clue as to the fact that the book itself is a translation from Turkish into English is conspicuous by its absence on the back cover as well. The quotes therein selected to promote the book point to the timely nature of its release while highlighting that Turkey is going through a state of crisis. For instance, Patrick Cockburn, the author of The Rise of Islamic State, hails the book as one that "gives a fascinating if frightening insight into the reasons why Turkey is becoming an authoritarian state." In a similar vein, Jodie Ginsberg from Index on Censorship praises the author for her courage to write this book as in the following: "Ece Temelkuran stares modern Turkey squarely in the eye to give a clearsighted view of the crisis gripping the country." Therefore, it is emphasised that the book corresponds to an increased level of curiosity about the dynamics behind the transformation of the author's country. Additionally, another commonality of the 
selected quotes which make a particular reference to the author is the stress being laid on Temelkuran's bravery and victimhood at the same time.

Considered together with the selection of these peritexts, it is also possible to note a tendency to highlight the timely nature of the book's release in the epitexts such as book reviews found on the internet. For instance, William Armstrong asserts that the book would not have appeared during the heyday of the "Turkish model", that is, when the West perceived Turkey as a country that successfully married democracy, free market and pragmatic Islam (Armstrong, 2016). Accordingly, critical voices like Temelkuran began to be heard and taken seriously only after the idea of viewing Turkey's system as a template for other Muslim countries to follow fell out of favour. Relatedly, most reviewers portrayed the author as a victim who lost not only her job but also her prominent media presence in Turkey while referring to Temelkuran's recognition as one of the country's most widely read writers and journalists (Armstrong, 2016; Leser, 2016). Therefore, as Cecilia Alvstad notes, these epitexts fulfil an important function in that they "frame the literary work in a way similar to peritexts", and hence are arguably complementary to the findings of the peritextual analysis (Alvstad, 2012, p. 90).
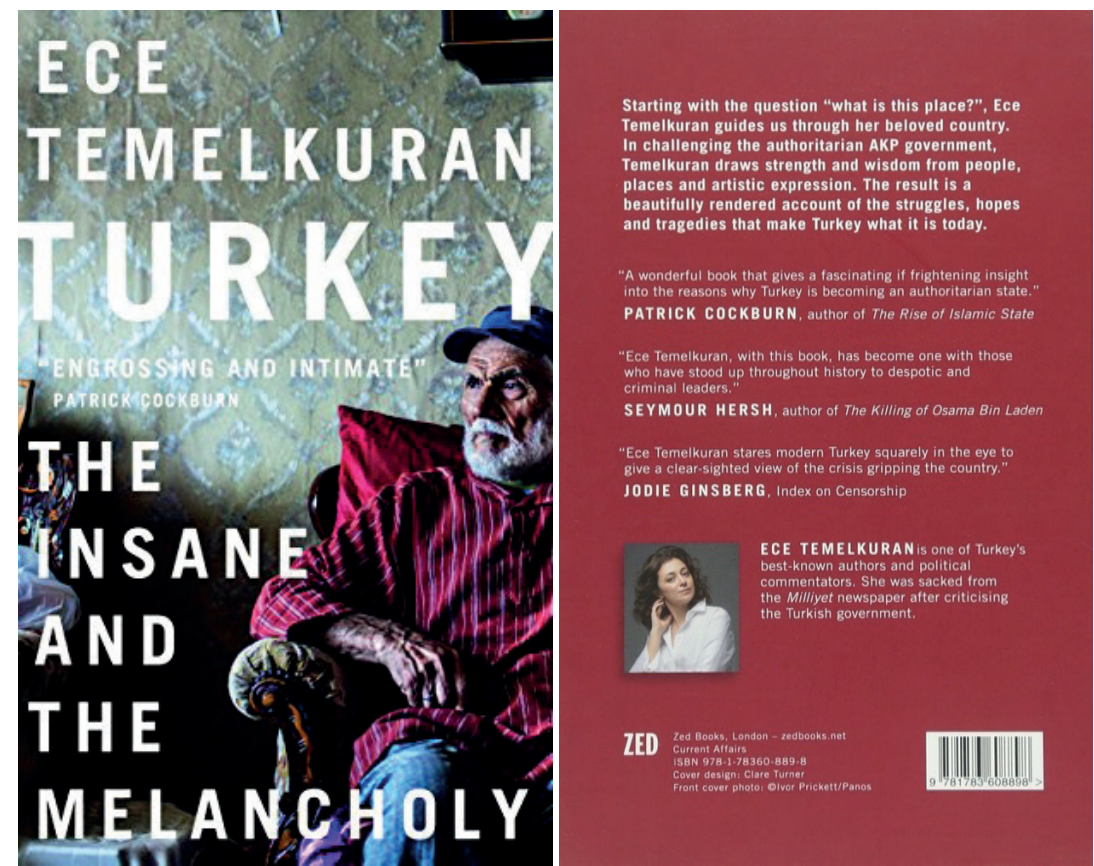

Figure 1. Front and back covers of Turkey: The Insane and The Melancholy, published by Zed Books in 2016. 
On the back cover, a short bio of the author is placed next to her picture on the bottom part, describing Temelkuran as"one of Turkey's best-known authors and political commentators." This is followed by the information that the author was sacked from the Milliyet newspaper after criticising the government. Crucially, this piece of information is incorrect in that Temelkuran worked as a columnist for the newspaper in question until being transferred, in 2010, to another mainstream newspaper, the Habertürk daily. Therefore, it was not the Milliyet but Habertürk newspaper from which the author was fired in early 2012 due to her criticism of the government. Inside the book, there is a section where the author explains the course of events that led to her loss of the job without particularly mentioning the name of this newspaper. This false information not only appears in the author's bio inside the book but also is used in some of the reviews mentioned above.

As for the front cover of Women Who Blow on Knots, the author's name appears on the top, being followed by the English translation of the title, as seen in Figure 2. Additionally, it is included on the front cover that the book is a winner of the Pen Translates Award, which is granted to UK publishers to "help promote, market and champion these titles" and thus to "celebrate books of outstanding literary value, dedication to free speech and intercultural understanding, which have a clear link to the PEN charter" (English PEN, 2004, para. 1). It can thus be inferred that the prize played a facilitating role in the publication of Women Who Blow on Knots in the UK. In addition to the information that the book received the First Book Award and the English Pen Award, Boyd Tonkin's quote, which is taken from Tonkin's book review on The Spectator, is selected to appear on the front cover, which reads: "Temelkuran has zest, and heart, and guts, to spare... a beach-read with brains and bounce" (Tonkin, 2017, para 5). The excerpt taken from Tonkin's review constitutes an illustrative example for the epitext that becomes part of the book and serves as the publisher's peritext. In parallel, the message that it conveys is arguably complementary to the promotional descriptions of the book such as "engaging", "funny" and "fast-paced" that appear on its back cover, as will be noted below.

The cover image features a vintage white Chevrolet in open barren, and an arm is stretched out of the car's window with a chador in the hand of the woman holding it away. Unlike The Insane and The Melancholy, it is possible to make a comparison with the version published in its country of origin, which can help us better identify how the promotional material recontextualised the translation in an English-speaking literary 
market. The front cover of the book's UK publication bears a significant resemblance to the one in the Turkish version in terms of the use of the same visual. However, the fact that the Tunisian Revolution, also known as the Jasmine Revolution, sets the background for the story is made more visible on the front cover of the Turkish version, as seen in Figure 3. This is achieved through the selection of the background colour as purple along with the use of jasmines scattered in the air around the same Chevrolet. In addition to the omission of jasmines, the UK cover replaces the lilac colour with a sepia-like tone, which is evocative of a dessert-like place.

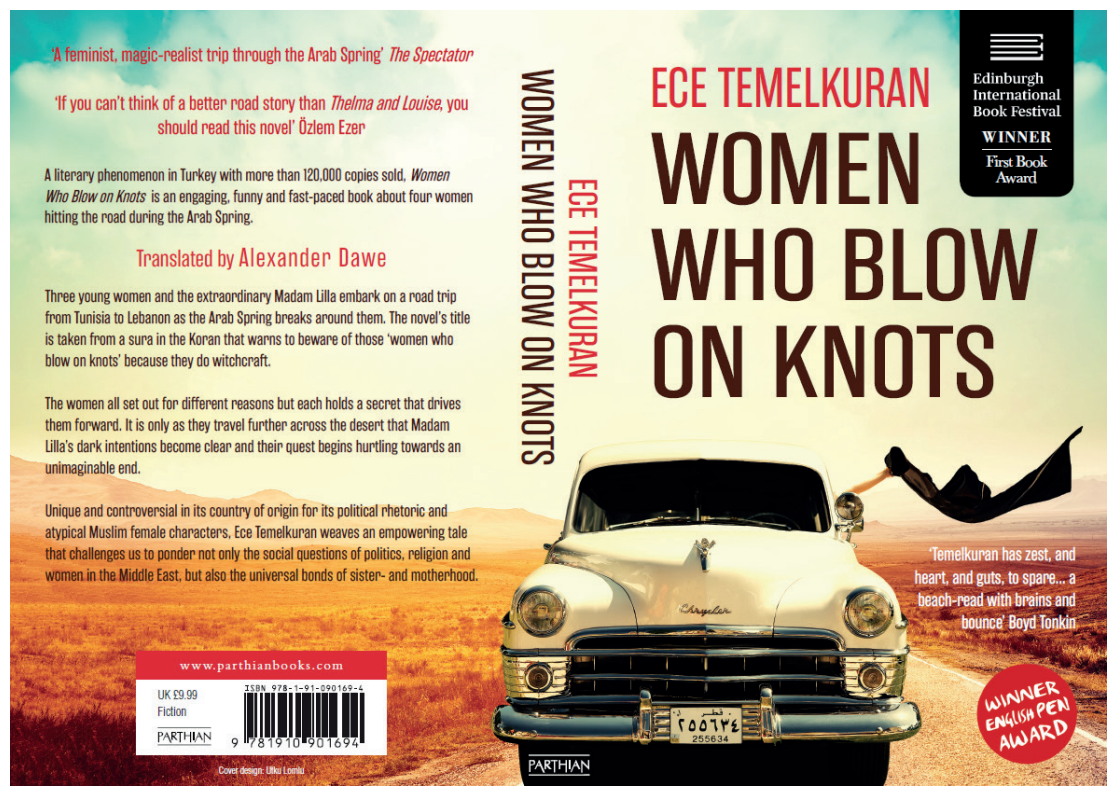

Figure 2. Front and back covers of Women Who Blow on Knots, published by Parthian Books in 2017.

Unlike The Insane and The Melancholy, one of the peritexts that follow the front cover in Women Who Blow on Knots includes a one-page section entitled "About the translator", which informs the reader about Alexander Dawe's academic education and previous translations from Turkish into English such as Sabahattin Ali's Madonna in Fur Coat. The publisher's addition of Dawe's background and earlier achievements serves not only to make the translator's work even more visible but also to add to the literary recognition of the work. The main text is followed by the information that the book "was selected to receive financial assistance from English Pen's 'Pen Translates' programme supported by Arts Council England" (Temelkuran, 2017). Crucially, an insight into the mission of English PEN is also provided as in the following: 
English PEN exists to promote literature and our understanding of it, to uphold writers' freedoms around the world, to campaign against the persecution and imprisonment of writers for stating their views, and to promote the friendly co-operation of writers and the free exchange of ideas. (Temelkuran, 2017)

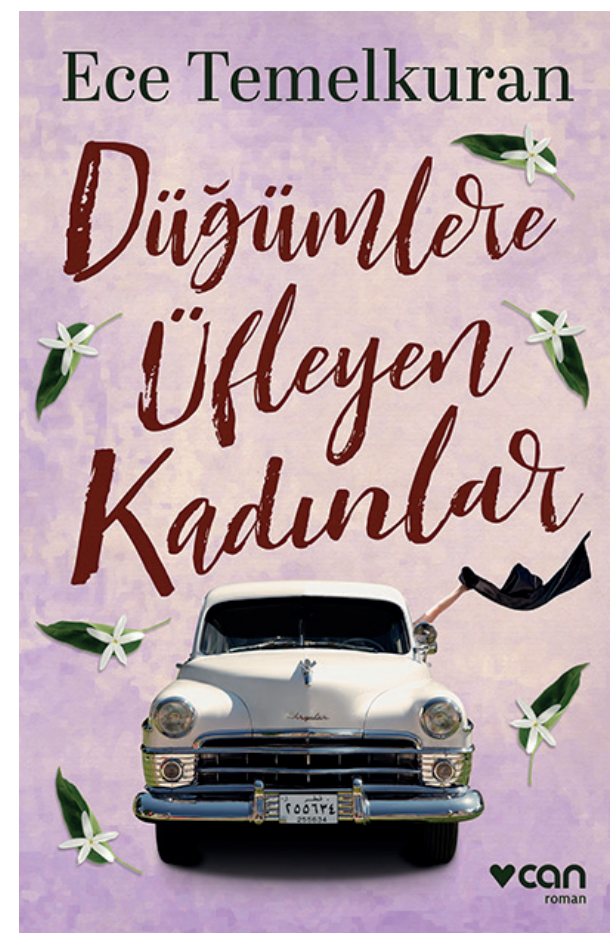

Figure 3. The front cover of the edition of Dügümlere Üfleyen Kadınlar (Women Who Blow on Knots), published by Can Publishing in Turkey in 2016.

On the back cover, the blurb introduces the main characters to the reader, without giving their names, as "atypical Muslim female characters."It provides information about the primary conflict, the Arab Spring, to intrigue the reader's interest by promising to depict a recent significant phenomenon that affected several countries across the Middle East. In doing so, the blurb also explains the meaning of the title by clarifying that it is taken from a sura in the Quran. Crucially, the book's Turkish version, published in Turkey by Can Publishing, does not include a similar explication although the phrase does not necessarily speak for itself in Turkish as well. The blurb also wants the reader to appreciate the universal nature of the story as one of sisterhood. It is designed to 
increase the appeal by referring to the book's popularity in its country of origin as "a literary phenomenon" and including the number of copies sold. The book is described as "unique and controversial for its political rhetoric." Additionally, two quotes of praise appear on the back cover, the first of which is an excerpt taken from Boyd Tonkin's review on The Spectator. Referring to the book as "a feminist, magic-realist trip through the Arab Spring", this one thus refers to the social and political context in which the story takes place. The second quote by Özlem Ezer lauds the book for celebrating the power of female friendship as in the following: "If you can't think of a better road story than Thelma and Louise, you should read this novel." Finally, although the translator's name again does not appear on the front cover, Parthian Books features the name of the translator, Alexander Dawe, on the back cover.

\section{Discussion}

A closer look at the peritextual elements of two different books by the same author lays bare the significance of each publisher's aim and scope in defining the physical presentation of translated works from Turkey to the English-speaking readership. For instance, according to the information found on its website, Zed Books, the publisher of The Insane and The Melancholy, "publishes socially and politically meaningful books" that are intended "for general readers, as well as for the academic market, with writers from around the world." ${ }^{\prime 1}$ Additionally, it highlights internationalism as part of its social mission, which involves"the translation of works, commissioning and supporting writers based internationally."In parallel, the publisher describes itself as a platform for publishing the work of marginalised individuals and groups across the globe. In contrast, Parthian Books, one of the independent publishers in Wales, "publishes a range of contemporary fiction, poetry, non-fiction and drama, as well as art books." ${ }^{2}$ They define their motto as accommodating a carnival of voices in independent publishing. Therefore, when compared to the focus on the literary success and merit of a book to be published in the case of Parthian Books, Zed Books prioritises the topicality of a book and its appeal to the interest of an international audience at the time of its intended publication. Given these differences in the priorities of these two publishers, it can be suggested that genre played a key role in the author's decision to work with Zed Books for The Insane and The Melancholy and Parthian Books for Women Who Blow on Knots.

1 See the website of Zed Books: https://www.zedbooks.net/about/zed-books/.

2 See the website of Parthian Books: https://www.parthianbooks.com/pages/about-us-1. 
Likewise, a comparative look at the physical presentation of these books of different genres by the same author enables us to discuss the link between the publisher's motivation for selecting a work for publication and its choice of peritextual elements. For instance, the front cover of The Insane and The Melancholy provides a case in point of how the preferred title interacts with the selected visual in line with the publisher's strategy for promoting the book. As seen in Figure 4, the font size of Turkey, which is distinctly larger than the rest of the title, draws the target reader's attention to the focus of the book, the author's native country. At the same time, the placement of The Insane and The Melancholy on the left side of the cover right next to the elderly man allows for a dual interpretation as to what this visual is intended to signify. The possible question that may come to mind at this point is whether the selected image is intended to represent the country that the book is about or the citizens of Turkey.

This potential for (mis)interpreting the interaction between these two peritexts is facilitated by the publisher's decision not to provide any information as to the original context from which the visual and the line are taken. Therefore, it can be suggested that there is an intended vagueness on the part of the publisher to create a double meaning and thus raise the reader's interest in the book. Indeed, based on the information that Temelkuran shared about the identity of the elderly man, this visual is understood to offer a contextual backdrop to the analysis presented therein. However, the reader remains oblivious to the real reference point, that is, the resistance against the government-led policies of urban transformation. Therefore, as seen in this example, the visual used on a book cover offers significant insights for the paratextual study of a translation (Eker Roditakis, 2015, p. 289). 


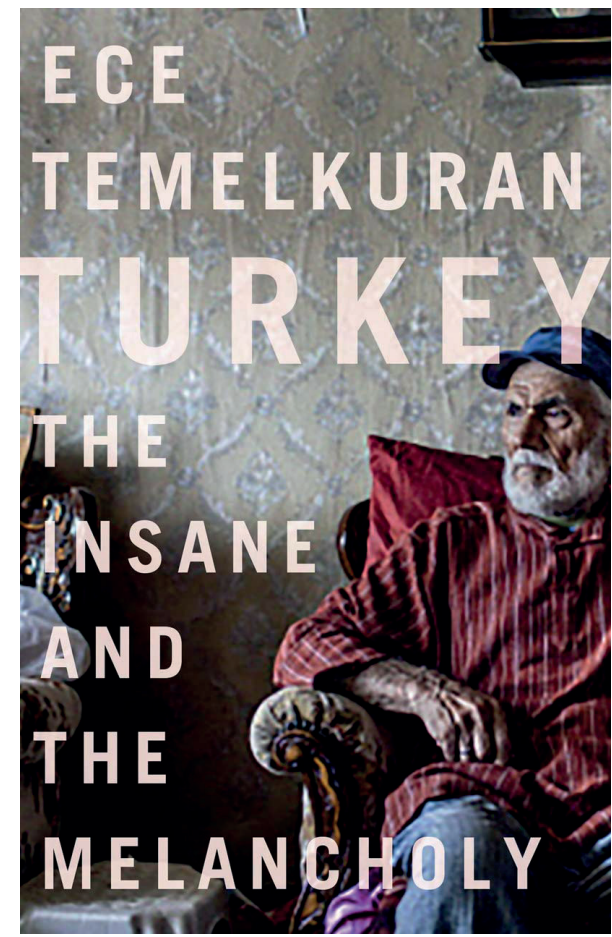

Figure 4. The front cover of Temelkuran's Turkey: The Insane and The Melancholy.

On the other hand, the fact that «Turkey» is foregrounded as part of the book's title can be revealing about the priorities and/or demands of the literary market in the UK. Crucially, since the book was not published in Turkey, it is not possible to make a comparison not only between the source and target texts but also between the paratexts of the source text and those of its translation. However, a comparison between the book's titles in different languages shows that the «Turkey» part is an addition of the UK publisher. Accordingly, the book was published in Germany with the title of Euphorie und Wehmut: die Türkei aufder Suche nach sich selbst, which literally translates as Euphoria and Melancholy: Turkey in search of herself. As is seen here, «Turkey» also appears in the German title but is accompanied by a descriptive phrase. Additionally, Temelkuran's publisher in Turkey refers to the book simply as Çılgın ve Hüzünlü (The Insane and the Melancholy) on its website without adding the «Turkey» part. $^{3}$ It is thus understood that it was the UK publisher's choice to select this combination of the title and the subtitle for promoting the book.

3 See the author's page in Turkish on the following website of Can Publishing: https://canyayinlari.com/ kisidetay/yazarlar/12749/ece-temelkuran/ 
An interview with the translator, Zeynep Beler, also reveals that this was the case. ${ }^{4}$ Accordingly, Beler tells the publisher that she found the title «Turkey: The Insane and The Melancholy» stupid and wanted to change it by discarding the «Turkey» part, but Zed Books says that it is way better than just The Insane and the Melancholy and that they were going to keep it. Therefore, this example shows that the translator did not have a say in the decision-making process of selecting the title in the case of The Insane and The Melancholy. This lack of agency may be deemed as unsurprising, given that the publisher did not prefer to render the translator's role visible on the front and back covers of the book.

Beler's objection can also be found rightful because the publisher's choice arguably blurs the intended meaning of the second part of the title, which is in fact a line from the poem of a well-known poet Turgut Uyar, entitled Çılgın Hüzünlü, which may be literally translated into English as Insane Melancholic. However, there is no information found in or outside the book as to the original source of this title. Considering together with the publisher's diagnosis of the state of Turkey as a country undergoing a dramatic change and suffering in the grip of a crisis, the choice to present «Turkey» with the subtitle of «The Insane and the Melancholy» may have been considered as deliberately provoking and intending to arouse curiosity.

This example also shows that Zed Books and Parthian Books differed from one another in their approach to the translators involved in these projects. The English title Women Who Blow on Knots, which is a literal translation of the Turkish title Dügümlere Üfleyen Kadınlar, highlights the role of women as the leading characters in the novel. Although the Turkish title is easily translatable from the language perspective, the translator Alexander Dawe explains in the same interview that the publisher's choice was to use the title What's a Revolution if You Can't Dance? in line with the other titles of the book in different languages. For instance, the German title is Was nützt mir die Revolution, wenn ich nicht tanzen kann? (What use is the revolution if I can't dance? in English), and the Polish one Taniec w rytmie rewolucji (Dance to the rhythm of the revolution in English). However, Dawe decided that it was wonderful and should go with the translation of the Turkish title. Therefore, this represents a case in which the translator's agency extended to the selection of a peritext such as the book's title. 
I argue that this was related to both the publisher's policy and promotional strategy about the book and the type of the book to be promoted. The fact that the former was an example of a non-fictional book and the latter a literary translation arguably made a difference in this role that the translators played. Additionally, it can be suggested that the recognition of a translator in the target literary market also played a role in Alexander Dawe's decisive role in the selection of the title. This recognition can also be linked to the presence or absence of a project that provides a framework for publishing a book. For instance, Women Who Blow on Knots was published in the UK within the framework of the Europe Carnivale series, "a collection of new European fiction and poetry, " written by contemporary female authors. ${ }^{5}$ This framework arguably also facilitated the publisher's receipt of the Pen Translates Prize for the completion of the translation project.

In return, the receipt of this prize may have rendered the translator's recognition inevitable in Dawe's case. Crucially, however, some reviews on The Insane and The Melancholy did not even mention that the book was a translation in line with the publisher's choice of downplaying the translator's role in the presentation of the book (Armstrong, 2016; Leser, 2016). Therefore, these two different cases demonstrate that the recognition of the translator's work is more visible in the case of an English translation which is assigned for the book's literary success in its country of origin rather than for the timeliness of the political commentary that it provides.

The analysis of the paratexts of these English translations also shows that "the creation of paratexts is a process of translation in a broad sense, in which the source is adapted so as to fit with what the publisher anticipates to be the needs and expectations of the target system" (Alvstad, 2012, p. 79). For instance, the adaptation of the front cover in the English translation of Women Who Blow on Knots can be considered in this regard. Translation here involves the substitution of the lilac colour for a sepia-like tone and the deletion of jasmines. Accordingly, the sepia tone is intended to evoke the desert landscape as the background in a way to present a conventional image of the Middle Eastern region. Crucially, this type of translation serves to have a streamlining effect on the national and ethnic identity of all these different female characters in the same way that the blurb labels them as "atypical" Muslim women. Therefore, as Sapiro emphasises, translation is used here to"reinforce more or less stereotypical representations of foreign cultures" (Sapiro, 2008, p. 163).

5 See the publisher's website for further information on the Parthian Europe Carnivale project: https://www. parthianbooks.com/blogs/news/europa-carnivale. 
Nevertheless, the UK publication of a non-fictional book in the form of a political commentary on Turkey in 2016 arguably contributed to the recognition of Temelkuran as a journalist who also published literary works in her own country. Given that Women Who Blow on Knots had originally been published in Turkey in 2013, it can be suggested that this recognition paved the way for Temelkuran's fictional works to be considered for publication in the UK market. Therefore, the burden of translation that Arif Dirlik (2002) noted as being forced upon «minority» writers in the global markets operated as the power of translation in Temelkuran's case, as the author not only gained literary recognition but also made her voice heard abroad as a political commentator on Turkey's current affairs.

\section{Conclusion}

This study focused mainly on the peritextual features of Temelkuran's Turkey: The Insane and The Melancholy and Women Who Blow on Knots, translated into English and published in the UK in 2016 and 2017, respectively. More specifically, I analysed the front and back covers of the translations without discussing the external discourses surrounding these translations. The comparative study of the peritextual features of these English translations provided a glimpse into the social and political context in which these books were translated and published in the UK. The references to the epitextual material such as book reviews and publicity material from book festivals and awards enabled us to demonstrate how the epitexts recontextualised translated works in a way similar to these peritexts. The analysis also allowed us to discuss the role of the publisher's motivations for the selection of a particular title by a particular author in defining several peritextual elements from the visual to the title to be used on the front cover. Additionally, the overview of the reception of female Turkish writers in translation in the UK facilitated a better comprehension of the recontextualisation of Temelkuran's works in the English-speaking industry.

One significant conclusion that can be drawn from this comparative analysis of the paratextual (mainly peritextual) elements of the two English translations is that the books selected for publication based on their literary merit provide more room for the author to release the burden of political signification and be appreciated for their creativity. Relatedly, another conclusion to be drawn from the analysis is that the translator's name and work are more likely to be recognised in the case of an English translation which is selected to be published for its literary success in its country of origin rather than for the timeliness of the political commentary that it provides. 
In terms of situating the study in the related field and its contribution to the scholarship on the presentation and consumption of translated literature from Turkey abroad, these conclusions can be compared to the other cases in which Turkish writers suffered the burden of translation and political signification. Accordingly, Temelkuran's case represents both continuity and change in terms of the status and role of Turkish women writers in translation. On the one hand, translations of Temelkuran's books are necessarily linked to a broader discourse on Turkey's identity and status in world politics. On the other hand, Temelkuran turns the burden of translation into an advantage as it enables her to convey her observations on Turkey and world politics to her followers. It is particularly critical to note that writing for and publishing in the English-speaking and global markets provide a shelter for an oppositional voice like Temelkuran, considering that the author is deprived of a mainstream platform in Turkey to write her commentaries in Turkish. Therefore, it can be argued that it is not categorically undesirable and/or burdensome for these Turkish writers to see that the interest in their works is due to the expectation from them to speak about their communities and provide an insight into the history, politics and cultural identity of their home country. Future research can be done to gain a deeper understanding of the production and consumption of the translations of these literary and non-literary works by mainly focusing on their epitextual features and discussing external discourses surrounding the texts as well as the textual analysis.

Peer-review: Externally peer-reviewed.

Conflict of Interest: The author has no conflict of interest to declare.

Grant Support: The author declared that this study has received no financial support.

Hakem Değerlendirmesi: Dış bağımsız.

Çıkar Çatışması: Yazar çıkar çatışması bildirmemiştir.

Finansal Destek: Yazar bu çalışma için finansal destek almadığını beyan etmiştir.

\section{References}

Adil, A. (2006). Western eyes: Contemporary Turkish literature in a British context. In G. MacLean (Ed.), Writing Turkey: explorations in Turkish history, politics, and cultural identity (pp. 129-143). London: Middlesex University Press.

Akbatur, A. (2011). Turkish women writers in English translation. MonTI. Monografias de Traduccion e Interpretacion, 3, 161-179. https://doi.org/10.6035/MonTI.2011.3.6 
Alvstad, C. (2012). The strategic moves of paratexts: World literature through Swedish eyes. Translation Studies, 5(1), 78-94. https://doi.org/10.1080/14781700.2012.628817

Armstrong, W. (2016, 23 December). Why is Turkey so divided?. Times Literary Supplement. Retrieved from https://www.the-tls.co.uk/articles/why-is-turkey-so-divided/

Batchelor, K. (2018). Translation and paratexts. London \& New York: Routledge.

Demirkol Ertürk, Ş. (2019). Retranslating and repackaging a literary masterpiece from a peripheral language: The functions of paratexts in recontextualizing literary translation. In Ö. Berk Albachten and Ş. Tahir Gürçağlar (Eds.), Studies from a retranslation culture: the Turkish context (pp. 137-154), Singapore: Springer.

Dirlik, A. (2002). Literature/identity: Transnationalism, narrative and representation. Review of Education, Pedagogy, and Cultural Studies, 24(3), pp. 209-234. https://doi.org/10.1080/10714410213688

Edinburgh International Book Festival. (2017, 1 November). Turkish author wins 2017 book festival first book award. Retrieved from https://www.edbookfest.co.uk/news/turkish-author-wins-2017-book-festival-firstbook-award

Eker Roditakis, A. (2012). A paratextual look at the Greek translations of Turkish novels. I.Ü. Çeviribilim Dergisi V, (1), pp. 39-68.

Eker Roditakis, A. (2015). The identity metonymics of translated Turkish fiction in English: The cases of Bilge Karasu and Orhan Pamuk. In Ş. Tahir Gürçağlar, S. Paker and J. Milton (Eds.), Tradition, translation and tension in Turkey (pp. 273-296), Amsterdam and Philadelphia: John Benjamins.

English PEN. (2004, 20 August). Who we are. Retrieved from https://www.englishpen.org/translation/who-we-are/ Genette, G. (1997). Paratexts: Thresholds of interpretation. Cambridge: Cambridge University Press.

Gümüş, S. (2007, 19 April). Adalet Ağaoğlu: Batı'ya çok fazla bakılıyor (Adalet Ağaoğlu: People look too much to the West). Radikal Daily. Retrieved from http://www.radikal.com.tr/kultur/adalet-agaoglu-batiya-cok-fazlabakiliyor-811785/

Gürsoy Sökmen, M. (2002). Being a woman publisher in Islamist country. Bianet. Retrieved from http://bianet. org/english/people/14841-being-a-woman-publisher-in-islamist-country

Kovala, U. (1996). Translations, paratextual mediation, and ideological closure. Target 8(1), 119-147. https://doi. org/10.1075/target.8.1.07kov

Leser, S. (2016, 4 November). Language is a battlefield: An interview with Turkish writer Ece Temelkuran. The culture trip. Retrieved from https://theculturetrip.com/europe/turkey/articles/language-is-a-battlefieldinterview-with-turkish-writer-ece-temelkuran/

Munday, J. (2016). Introducing translation studies: Theories and applications ( $4^{\text {th }}$ ed.). New York: Routledge.

Paker, S. (2001). Turkish. In P. France (Ed.), The Oxford guide to literature in English translation (pp. 619-624). Oxford: Oxford University Press.

Sapiro, G. (2008). Translations and the field of publishing: A commentary on Pierre Bourdieu's "A conservative revolution in publishing". Translation Studies 1(2), 154-166. https://doi.org/10.1080/14781700802113473 
Tahir Gürçağlar, Ş. (2002). What texts don't tell: the uses of paratext in translation research. In T. Hermans (Ed.), Crosscultural transgressions. Research models in translation studies II Historical and ideological issues (pp. 4460). Manchester: St. Jerome.

Tahir Gürçağlar, Ş. (2011). Paratexts. In Y. Gambier and L. van Doorslaer (Eds.), Handbook of Translation Studies Volume 2 (pp. 113-116). Amsterdam. \& Philadelphia: John Benjamins.

Tahir Gürçağlar, Ş. (2015). The "official" view on translation in Turkey: The case of national publishing congresses (1939-2009), In Ş. Tahir Gürçağlar, S. Paker and J. Milton (Eds.), Tradition, Translation and Tension in Turkey (pp. 125-144), Amsterdam and Philadelphia: John Benjamins.

Tekgül, D. (updated by A. Akbatur). (2013). Literary translation from Turkish into English in the United Kingdom and Ireland, 1990-2012. Mercator Institute for Media, Languages and Culture Aberystwyth University, Wales, UK. Retrieved from http://www.lit-across-frontiers.org/wp-content/uploads/2013/03/LiteraryTranslation-from-Turkish-into-English-in-the-UK-and-Ireland-1990-2012-WITH-NEW-UPDATE.pdf

Temelkuran, E. (2016). Turkey: The insane and the melancholy. (Z. Beler, Trans.). London: Zed Books.

Temelkuran, E. (2017). Women who blow on knots. (A. Dawe, Trans.). New York: Pantheon Books.

Tonkin, B. (2017, 8 July). Hot spring. The Spectator. Retrieved from https://www.spectator.co.uk/article/hotspring

Uslu, M. (2012). Representation of the Turkish literature in English: Translations of short stories as a case. I.Ü. Çeviribilim Dergisi, 5(1), pp. 1-38.

von Flotow, L. (2012). Translating women: From recent histories and re-translations to "queerying" translation, and metamorphosis. Quaderns Revista de Traducciò, 19, pp. 127-139. 
